\title{
The influence of boar breed and season on semen parameters
}

\author{
D. Knecht, S. Środoń \& K. Duziński ${ }^{\#}$ \\ Institute of Animal Breeding, Wroclaw University of Environmental and Life Sciences, Poland
}

(Received 1January 2013; Accepted 9 September 2013; First published online 29 January 2014)

Copyright resides with the authors in terms of the Creative Commons Attribution 2.5 South African Licence.
See: http://creativecommons.org/licenses/by/2.5/za
Condition of use: The user may copy, distribute, transmit and adapt the work, but must recognise the authors and the South African
Journal of Animal Science.

\begin{abstract}
The aim of the present study was to demonstrate the influence of boar breed and season on semen parameters. The research material consisted of 31 boars: Polish Large White (PLW), Polish Landrace (PL), and Duroc $\times$ Pietrain $(D \times P)$, aged 8 to 24 months. The analysed material consisted of 1390 ejaculates, collected during the period January 2010 to October 2012. Semen samples were assessed in terms of semen volume $(\mathrm{mL})$, sperm concentration $\left(\times 10^{6} \mathrm{~m} / \mathrm{mL}\right)$, total number of sperm $\left(\times 10^{9}\right)$, total number of live sperm $\left(\times 10^{9}\right)$ and number of insemination doses obtained from one ejaculate $(n)$. In winter, an increase in sperm concentration was observed for the PLW breed. Moreover, an increase in the volume of semen produced for this breed was noted in summer and autumn. Differences between breeds for the total number of sperm and total number of live sperm were observed for the winter and spring periods. The largest semen volume was noted for the PLW breed $(276.4 \pm 9.66 \mathrm{~mL})$. However, in the analysis of other sperm parameters, boars of this breed demonstrated the poorest results. The highest insemination dose was obtained from breed $\mathrm{D} \times \mathrm{P}$ in winter $(26.0 \pm 0.51)$. Correlation analyses indicated that $\mathrm{PLW}$ and $\mathrm{D} \times \mathrm{P}$ boars are the least resistant to higher ambient temperatures, and in summer and autumn this resulted in a reduction in sperm concentration $(-0.26$ and -0.20 , respectively).
\end{abstract}

Keywords: Breed, boars, ejaculate, season, semen quality

\# Corresponding author: kamil.duzinski@up.wroc.pl

\section{Introduction}

The continuous development and popularity of artificial insemination (Al) in pigs have driven the rate of high-performance insemination dose production intended for production distribution not only in Poland, but around the world. Eliminating all differentiating factors to produce the most homogeneous biological material is important, especially in insemination dose production. The quality and quantity of semen used for artificial insemination is determined by the main parameters; volume, sperm concentration, number of live sperm and number of insemination doses obtained from one ejaculate after dilution, all of which are sometimes difficult to interpret (Smital et al., 2004).

Problems with fertilization, in addition to sow disorders, can be influenced by the quality of semen from the male (Chenoweth, 2005). The quantity and quality of ejaculates are affected by animal and environmental factors such as breed, age, feeding, health status and season (Cheon et al., 2002). The seasonality of breeding performance in sows and boars is often discussed in the literature (Peltoniemi et al., 2000; Strzeżek et al., 2000; Basset et al., 2001; Tast et al., 2001). Changes in the composition of semen during the year may vary between $25 \%$ and $30 \%$ (Colenbrander \& Kemp, 1990). The main determinant of daily sperm production is the number of Sertoli cells, which is determined by testes mass (Okwun et al., 1996; Ford et al., 2006). Currently, strong emphasis is being placed on the impact of sires on offspring, and this is especially so in insemination where the number of offspring of one sire is significant.

A temperate climate can be defined as a climate where there is a distinct difference in the minimum and maximum temperatures recorded during the seasons, and also in the number of sunshine hours, rainfall, humidity and number of daylight hours. Complex meteorological factors must be taken into account, which include the microclimate of the season, with particular emphasis on temperature, especially in intensive pig production. The length of daylight regulates reproduction in wild boars, the ancestor of the domestic pig (Popiołek et al., 2010), with synchronization supported mostly by temperature and the amount of food (Kozdrowski \& Dubiel, 2004). 
Each opportunity to identify and eliminate variables influencing the quality of ejaculates should contribute to an increase in the number of insemination servings available for use in insemination programmes (Sancho et al., 2004). Temperature is accorded a special role among environmental factors (Corcuera et al., 2002). This is understandable, because it is a factor with a significant effect on differences between seasons. Positive effects are induced by the body's exposure to sunlight and movement, which can be associated with the production of vitamin D in males (Kinuta et al., 2000; Bouillon et al., 2008; Blomberg et al., 2011). Alternatively, it is suggested that light intensity is more important than daylight length (Okere et al., 2005). Better knowledge of the factors affecting the quantity and quality of ejaculates results in the improved efficiency of biological, organizational and economical insemination. Therefore, it is reasonable to carry out research in this field, focusing on both the external environmental conditions and genotype. The profitability level of Al centres is determined by the basic semen traits, and therefore the search for indicators impairing the productivity of insemination portions is important (Robinson \& Buhr, 2005; Wolf \& Smital, 2009). In recent years, Al has been widely implemented in the production of pigs. Therefore, the choice of boars is becoming increasingly important and urgent to the pig industry (Ren et al., 2009). Understanding the basic genetic differences between the male reproductive traits of different breeds of boars is necessary to increase the efficiency of sperm production in insemination stations (Safranski, 2008). One solution that can improve the situation of the insemination station is the introduction of a low number of sperm technologies (post-cervical, deep uterine, laparoscopic insemination), especially at the time of the decrease in production of sperm by the boars during high temperatures (Gerrits et al., 2005).

The aim of the present study was to demonstrate the influence of boar breed and season on semen parameters in industrial piggeries located in a temperate climate.

\section{Material and Methods}

Animals were housed in an industrial piggery in Opolskie Province, Poland, at $51.0431^{\circ} \mathrm{N}, 17.8583^{\circ} \mathrm{E}$. Semen samples were used in the preparation of insemination doses for their own production system. Thirtyone boars (12 PLW, $10 \mathrm{PL}, 9 \mathrm{D} \times \mathrm{P})$, aged between 8 to 24 months, were used in the study. Steps to eliminate the effect of age were taken in the research. In all seasons and age groups (8 - 10; $11-13 ; 14$ 16; 17 - 19; 20 - 22; 23 - 24 months) 2 to 4 boars were selected depending on the breed. The number of young, middle-aged and old boars in each season and breed was almost identical. The individual pen area was $10 \mathrm{~m}^{2} / \mathrm{boar}$, and the floor surface was concrete. Food intake was individualized for each boar according to Polish Swine Nutrition Requirements (1993), with ad libitum access to water. A summary of the metabolic energy was $30-37 \mathrm{MJ}$, digestible protein $340-420 \mathrm{~g}$, lysine $22-30 \mathrm{~g}$, methionine + cystine $15-20 \mathrm{~g}$, calcium $18-22 \mathrm{~g}$, phosphorus $13-16 \mathrm{~g}$ and sodium $3-5 \mathrm{~g}$ per $\mathrm{kg}$, depending on boar age and breeding performance. The microclimate in the area for boars was controlled automatically and remained at an optimal level for this group. The air temperature in all the boar pens was $15{ }^{\circ} \mathrm{C}$ (average minimum $12{ }^{\circ} \mathrm{C}$ and maximum $20^{\circ} \mathrm{C}$ ). Relative humidity was close to $75 \%$ ( $\min 65 \%$, max $85 \%$ ). The air circulation inside the building was equal to $0.15 \mathrm{~m} / \mathrm{s}$ in winter and $0.20 \mathrm{~m} / \mathrm{s}$ in the summer.

At 20 minutes before and after collection, boars were stimulated by short physical activity to meet their basic behavioural needs. This took place on an uncovered walk outside, leading to the place of semen collection. The ground there was soft (soil, sawdust), which allowed grouting. At this time, the males were exposed to external weather conditions. The boars were maintained in accordance with the principles of animal welfare (Ordinance of the Minister of Agriculture and Rural Development, 2010).

A total of 1390 ejaculates were collected (491 PLW, 421 PL, $478 \mathrm{D} \times \mathrm{P}$ ) in the period, January 2010 to October 2012. Ejaculates was collected by masturbation via a manual method (King \& Macpherson, 1973), using a container with filter. Semen samples were taken per boar in each season: winter (January, February, March), spring (April, May, June), summer (July, August, September) and autumn (October, November, December). The average number of samples in the season per boar varied, depending on the breed (PLW: 10.23, PL: 10.53, D $\times$ P: 13.28). Collections were made in almost homogeneous terms during the seasons (equal time intervals, including beginning, middle and end of the season) for all breeds with no significant deviations. Only the sperm-rich fraction was analysed. The gelatinous fraction was separated from the complete sample before analysis.

The traits analysed included semen volume $(\mathrm{mL})$, sperm concentration $\left(\times 10^{6} / \mathrm{mL}\right)$, total number of sperm $\left(\times 10^{9}\right)$, total number of live sperm $\left(\times 10^{9}\right)$ and the number of insemination doses obtained from one ejaculate (n). Immediately after collection, the volume of semen was measured with a scalar cylinder. The concentration of sperm was evaluated with a SpermaCue device (Model 12300/0500, Minitube International, Verona, USA). Based on semen volume and sperm concentration, the total number of sperm in the ejaculate was calculated. The vitality of the sperm was measured by a simple method developed for the commercial piggery laboratory, based on motile spermatozoa and sperm abnormal change visibility under the microscope without the addition of chemical reagents. In native semen, the percentage of motile 
spermatozoa was determined microscopically $(200 \times$ magnification). The percentage share of correctly motile spermatozoa among the total number of visible spermatozoa was determined (Bennett \& O'Hagan, 1964). Then, the percentage of motile spermatozoa and the total number of spermatozoa were multiplied to achieve the total number of motile spermatozoa. Semen dilution took place immediately after the assessment using a short-term BTS boar semen extender (Version 13525/0100 Antibiotic free, Minitube International, Verona, USA).

Each season during the years of the experiment, data on temperatures, humidity, number of sunshine hours and rainfall near the farm came from the Institute of Meteorology and Water Management-National Research Institute (Table 1). To calculate the correlation coefficients, the outside temperature for each day of semen collection was obtained, including the hour.

Table 1 Seasonal outdoor temperature $\left({ }^{\circ} \mathrm{C}\right)$, humidity (\%), sunshine hours $(\mathrm{h})$ and rainfall $(\mathrm{mm})$ recorded for the study location, from 1 January 2010 to 30 October 2012 (mean \pm SE)

\begin{tabular}{lcccc}
\hline Season & $\begin{array}{c}\text { Temperature } \\
\left({ }^{\circ} \mathbf{C}\right)\end{array}$ & $\begin{array}{c}\text { Humidity } \\
(\%)\end{array}$ & $\begin{array}{c}\text { Sunshine hours } \\
(\mathbf{h})\end{array}$ & $\begin{array}{c}\text { Rainfall } \\
(\mathbf{m m})\end{array}$ \\
\hline Winter & & & & \\
Spring & $-0.7 \pm 1.36$ & $75.0 \pm 1.57$ & $103.3 \pm 18.71$ & $35.6 \pm 4.44$ \\
Summer & $13.8 \pm 1.24$ & $69.3 \pm 2.14$ & $244.4 \pm 20.96$ & $63.9 \pm 15.32$ \\
Autumn & $17.3 \pm 1.05$ & $71.0 \pm 1.69$ & $240.0 \pm 15.09$ & $77.8 \pm 12.45$ \\
& $3.5 \pm 2.17$ & $75.5 \pm 1.43$ & $98.3 \pm 21.97$ & $38.3 \pm 10.78$ \\
\hline
\end{tabular}

The data were analysed using the STATISTICA (2012) statistical programme. The values in the tables were determined by calculating the mean $(\bar{x})$ and standard error (SE). The mixed model with the repeated measure statement was used with season as a permanent effect and breed as a random effect. The significance of differences between breeds and seasons was calculated based on Tukey's multiple range test. In addition, Pearson's correlation coefficient ( $r$ ) was calculated not only between the analysed parameters of semen within breeds, but also between semen parameters and temperature within each season. Levels of significance of differences were given conventionally: significant $0.01<P \leq 0.05$ and highly significant $P \leq 0.01$.

\section{Results}

The effect of season on selected parameters of semen is presented in Table 2. The highest sperm concentration was recorded during winter $(P \leq 0.01)$. Large differences were noted between this season and spring and summer $(P \leq 0.01)$. The semen volumes in spring and autumn were characterized by similar size. The lowest volume was observed in winter and the highest in summer $(P \leq 0.05)$. There were no statistically significant differences between seasons in terms of the total number of sperm and number of live sperm in the ejaculate. The changes in the total number of live sperm in the ejaculate were similar to those observed for the total number of sperm. Differences between seasons for the number of insemination doses were observed in winter and summer $(P \leq 0.05)$.

Table 3 shows the effect of breed on the general parameters of boar semen. The highest sperm concentration, compared with other breeds, was found in the $\mathrm{D} \times \mathrm{P}$ breed $(P \leq 0.01)$. For this parameter, differences among all investigated breeds were confirmed statistically $(P \leq 0.01)$. A large difference was observed in the amount of semen produced by PLW and D XP boars $(P \leq 0.01)$. Further analysis of the semen revealed that the PLW breed produced the lowest number of sperm per ejaculate, and sperm of this breed was characterized by a low number of live sperm $(P \leq 0.01)$. In terms of the number of insemination doses, the PLW breed had the worst results, compared with the other breeds $(P \leq 0.01)$.

The degree of dependence between the parameters of boar semen is presented in Table 4 . The calculations proved the tendency that with increasing semen volume, the concentration decreased. The largest relationship between these two parameters was observed for the PLW breed $(P \leq 0.01)$. Very high correlation coefficients were shown between the total number of sperm and the number of live sperm in the ejaculate and also the number of insemination doses. The strongest correlations between the total number of sperm and the number of live sperm were observed for the PLW and PL breeds $(P \leq 0.01)$. However, the highest correlation coefficient value between the total number of sperm and the number of insemination doses was recorded for the $\mathrm{D} \times \mathrm{P}$ breed $(P \leq 0.01)$. Moreover, a strong relationship was found between the 
number of live sperm in the ejaculate, and the number of insemination doses. The highest correlation coefficients were noted for the PLW and $\mathrm{D} \times \mathrm{P}$ breeds $(P \leq 0.01)$.

Table 2 Effect of season on selected semen traits analysed in the experiment (mean \pm SE)

\begin{tabular}{lcccc}
\hline \multirow{2}{*}{ Specification } & \multicolumn{4}{c}{ Season } \\
\cline { 2 - 5 } & Winter & Spring & Summer & Autumn \\
\hline Sperm concentration $\left(\times 10^{6} / \mathrm{mL}\right)$ & $388.3^{\mathrm{A}} \pm 4.89$ & $357.3^{\mathrm{B}} \pm 5.20$ & $356.8^{\mathrm{B}} \pm 4.86$ & $369.6 \pm 5.01$ \\
Semen volume $(\mathrm{mL})$ & $242.8^{\mathbf{b}} \pm 3.92$ & $253.0 \pm 3.82$ & $257.6^{\mathbf{a}} \pm 4.19$ & $254.0 \pm 4.58$ \\
Total number of sperm $\left(\times 10^{9}\right)$ & $90.2 \pm 1.24$ & $86.4 \pm 1.17$ & $86.6 \pm 1.06$ & $89.3 \pm 1.24$ \\
Total number of live sperm $\left(\times 10^{9}\right)$ & $74.6 \pm 1.04$ & $72.1 \pm 1.03$ & $72.2 \pm 0.96$ & $74.4 \pm 1.05$ \\
Number of insemination doses $(\mathrm{n})$ & $24.25^{\mathbf{a}} \pm 0.31$ & $23.31 \pm 0.28$ & $23.13^{\mathbf{b}} \pm 0.26$ & $24.14 \pm 0.29$ \\
& & & & \\
\hline
\end{tabular}

${ }^{\mathbf{a}, \mathbf{b}}$ different superscripts in columns denote significant differences between seasons $(P \leq 0.05)$.

$A, B$ different superscripts in columns denote significant differences between seasons $(P \leq 0.01)$.

Table 3 Effect of breed: PLW (Polish Large White), PL (Polish Landrace), D $\times$ P (Duroc $\times$ Pietrain), on semen traits (mean \pm SE)

\begin{tabular}{lccc}
\hline \multirow{2}{*}{ Specification } & \multicolumn{3}{c}{ Breed } \\
\cline { 2 - 4 } & PLW & PL & D $\times \mathbf{P}$ \\
\hline Sperm concentration $\left(\times 10^{6} / \mathrm{mL}\right)$ & $345.1^{\mathrm{Z}} \pm 4.79$ & $367.7^{\mathrm{Y}} \pm 3.79$ & $391.8^{\mathrm{X}} \pm 3.98$ \\
Semen volume $(\mathrm{mL})$ & $258.6^{\mathrm{X}} \pm 4.04$ & $251.6 \pm 2.96$ & $245.1^{\mathrm{Y}} \pm 3.43$ \\
Total number of sperm $\left(\times 10^{9}\right)$ & $82.9^{\mathrm{Y}} \pm 0.99$ & $89.9^{\mathrm{X}} \pm 0.97$ & $91.9^{\mathrm{X}} \pm 1.04$ \\
Total number of live sperm $\left(\times 10^{9}\right)$ & $68.8^{\mathrm{Y}} \pm 0.85$ & $75.0^{\mathrm{X}} \pm 0.85$ & $76.4^{\mathrm{X}} \pm 0.89$ \\
Number of insemination doses $(\mathrm{n})$ & $22.44^{\mathrm{Y}} \pm 0.24$ & $24.27^{\mathrm{X}} \pm 0.23$ & $24.47^{\mathrm{X}} \pm 0.25$ \\
\hline
\end{tabular}

$X, Y, Z$ in the same row signifies statistical significant differences between breeds, with $P \leq 0.01$.

The influence of season and breed of boar on selected semen parameters is shown in Table 5. For the sperm concentration in the PLW breed, the largest deviation from the average was observed in winter $(P$ $\leq 0.01$ and $P \leq 0.05$ ). The highest differences in this parameter were recorded between the PLW and $D \times P$ breeds in spring, summer and autumn $(P \leq 0.01)$. Statistical analysis using the mixed model with repeated measure statements confirmed the significant influence of breed $(F=17.99 ; P \leq 0.01)$ and season $(F=4.88$; $P \leq 0.05$ ) on the sperm concentration.

Analysis of semen volume in PLW boars showed the largest deviations between winter, and summer and autumn $(P \leq 0.01)$. The highest semen volume in the examined breeds was noted for the PLW boars in summer and autumn $(P \leq 0.05)$, and the lowest value in this period was observed for the $\mathrm{D} \times \mathrm{P}$ boars $(P$ $\leq 0.05)$. Analysis of variance for semen volume affirmed the interaction between breed and season $(F=4.17$; $P \leq 0.01)$.

The highest sperm concentration and percentage live sperm were recorded in winter for $D \times P$ boars $(P \leq 0.01)$. A large increase in the total number of spermatozoa was noted for the PLW breed in autumn $(P$ $\leq 0.05)$. For PLW boar semen, compared with other breeds, the lowest total number of sperm and number of live spermatozoa in the ejaculates were recorded in winter and spring $(P \leq 0.01)$. Statistical analysis confirmed the effect of breed on the total number of sperm $(F=5.48 ; P \leq 0.05)$ and the number of live sperm in the ejaculate $(F=6.23 ; P \leq 0.05)$. In addition, in these parameters the interaction between season and breed was observed $(\mathrm{F}=4.39 ; P \leq 0.01$ and $\mathrm{F}=3.86 ; P \leq 0.01)$. 
Table4 Correlation between sperm concentration $\left(\times 10^{6} / \mathrm{mL}\right)$, semen volume $(\mathrm{mL})$, total number of sperm $\left(\times 10^{9}\right)$, number of live sperm $\left(\times 10^{9}\right)$ and number of insemination doses $(n)$ including breed: PLW (Polish Large White), PL (Polish Landrace), D × P (Duroc × Pietrain)

\begin{tabular}{|c|c|c|c|c|c|c|}
\hline Specification & Breed & $\begin{array}{c}\text { Sperm } \\
\text { concentration } \\
\left(\times 10^{6} / \mathrm{mL}\right)\end{array}$ & $\begin{array}{c}\text { Semen } \\
\text { volume } \\
(\mathrm{mL})\end{array}$ & $\begin{array}{c}\text { Total number } \\
\text { of sperm }(x \\
\left.10^{9}\right)\end{array}$ & $\begin{array}{l}\text { Total number } \\
\text { of live sperm } \\
\left(\times 10^{9}\right)\end{array}$ & $\begin{array}{c}\text { Number } \\
\text { of insemination } \\
\text { doses } \\
(n)\end{array}$ \\
\hline \multirow{3}{*}{$\begin{array}{l}\text { Sperm } \\
\text { concentration } \\
\left(\times 10^{6} / \mathrm{mL}\right)\end{array}$} & PLW & 1 & & & & \\
\hline & $\mathrm{PL}$ & 1 & & & & \\
\hline & $D \times P$ & 1 & & & & \\
\hline \multirow{3}{*}{$\begin{array}{l}\text { Semen volume } \\
(\mathrm{mL})\end{array}$} & PLW & $-0.66^{\star \star}$ & 1 & & & \\
\hline & $\mathrm{PL}$ & $-0.55^{\star \star}$ & 1 & & & \\
\hline & $D \times P$ & $-0.63^{\star \star}$ & 1 & & & \\
\hline \multirow{3}{*}{$\begin{array}{l}\text { Total number of } \\
\text { sperm }\left(\times 10^{9}\right)\end{array}$} & PLW & $0.26^{\star \star}$ & 0.49 ** & 1 & & \\
\hline & $\mathrm{PL}$ & $0.31^{\star \star}$ & $0.58^{\star \star}$ & 1 & & \\
\hline & $\mathrm{D} \times \mathrm{P}$ & $0.12^{*}$ & $0.64^{\star \star}$ & 1 & & \\
\hline \multirow{3}{*}{$\begin{array}{l}\text { Total number of } \\
\text { live sperm } \\
\left(\times 10^{5}\right)\end{array}$} & PLW & $0.25^{\star \star}$ & 0.49 ** & $0.99 * \star$ & 1 & \\
\hline & $\mathrm{PL}$ & $0.31^{\star *}$ & $0.56^{\star \star}$ & $0.98^{\star *}$ & 1 & \\
\hline & $D \times P$ & $0.09^{*}$ & $0.59^{\star \star}$ & $0.92^{\star \star}$ & 1 & \\
\hline \multirow{3}{*}{$\begin{array}{l}\text { The number of } \\
\text { insemination } \\
\text { doses }(n)\end{array}$} & PLW & $0.22^{\star \star}$ & $0.46^{\star \star}$ & $0.93^{\star \star}$ & $0.92^{\star \star}$ & 1 \\
\hline & $\mathrm{PL}$ & $0.32^{\star \star}$ & $0.47^{\star \star}$ & $0.88^{\star *}$ & $0.88^{\star \star}$ & 1 \\
\hline & $D \times P$ & $0.12^{\star *}$ & $0.62^{\star \star}$ & 0.99 ** & $0.91^{\star \star}$ & 1 \\
\hline
\end{tabular}

${ }^{*}$ correlation statistically significant, with $P \leq 0.05$.

${ }^{* *}$ correlation statistically highly significant, with $P \leq 0.01$.

The largest number of insemination doses was obtained for the $\mathrm{D} \times \mathrm{P}$ breed in winter $(P \leq 0.01)$. Semen analysis for PLW boars showed that differences in the number of insemination doses occurred between spring and autumn $(P \leq 0.05)$. The highest number of insemination doses, in terms of breed, was recorded in winter and spring for the $D \times P$ breed $(P \leq 0.01)$. Analysis of the number of insemination doses using the general linear model allowed observation of the interaction for this parameter between breed and season $(F=4.68 ; P \leq 0.01)$.

\section{Discussion}

The seasonal effect of weather on boars can be observed, especially for the parameters, semen volume and total number of sperm (Claus \& Weiler, 1985). For example, the highest semen volume, above $220 \mathrm{~mL}$, was obtained in autumn and winter by Ciereszko et al. (2000). Although in our study, in winter seasons this index was very low, it still accounted for more than $240 \mathrm{~mL}$. The observed reduction in the volume of semen in the experiment could be caused by environmental conditions acting on boars directly before collection. On the other hand, the highest numbers for total and live sperm were observed in winter.

Regardless of breed, in the study conducted by Park \& Yi (2002) lower levels were noted for the number of live sperm in ejaculates. This ratio was approximately $1: 2$. Our study indicates that the value of this size was almost identical for the same seasons, which rendered support for the findings of Smital et al. (2004).

With an increase in volume, the total number of sperm increased, regardless of breed, which was slightly lower than the value shown by Kozdrowski \& Dubiel (2004) for wild boars $(r=0.76)$. The reason was probably an increase in seminal vesicle, prostate and bulbourethral gland activity during this period. Seasonal changes in the quantity and quality (including levels of sex hormones) of seminal plasma are caused by the variable action of these three male accessory glands (Strzeżek et al., 2000).

Higher activity of male glands as a result of semen parameters was noted in autumn and winter. The same interdependence was observed for wild boars residing all year in a changing external environment (Kozdrowski \& Dubiel, 2004). The hypothesis of an increased production of vitamin D and light intensity, which can affect the quantity and quality of the ejaculates, was not confirmed in short-stay boars outside the building before and after collection. In our study, temporary (summer) reduction in semen quality was noted. 
Rivera et al. (2005) have concluded that factors relating to temperature and humidity are more important than the length of daylight. In the opinion of Chokoe \& Siebrits (2009), temperature is a very important factor in natural mating. The studies by Wetteman \& Bazer (1985), Sonderman \& Luebbe (2008) and Flowers (2008) confirmed that thermal stress negatively affects sperm quality and ejaculation volume.

Table 5 Effect of season and breed PLW (Polish Large White), PL (Polish Landrace), D $\times$ P (Duroc $\times$ Pietrain) on semen traits (mean \pm SE)

\begin{tabular}{|c|c|c|c|c|c|}
\hline \multirow{2}{*}{ Specification } & \multirow{2}{*}{ Breed } & \multicolumn{4}{|c|}{ Season } \\
\hline & & Winter & Spring & Summer & Autumn \\
\hline \multirow{3}{*}{$\begin{array}{l}\text { Sperm concentration } \\
\left(\times 10^{6} / \mathrm{mL}\right)\end{array}$} & PLW & $380.9^{A, a} \pm 9.67$ & $329.0^{\mathrm{B}, \mathrm{Y}} \pm 10.48$ & $331.6^{\mathrm{B}, \mathrm{Y}} \pm 8.33$ & $336.3^{b, Y} \pm 9.14$ \\
\hline & $\mathrm{PL}$ & $374.5 \pm 7.92$ & $354.4 \pm 7.78$ & $366.5 \pm 7.30$ & $375.9 \pm 7.17$ \\
\hline & $D \times P$ & $409.3 \pm 6.82$ & $387.7^{x} \pm 7.50$ & $376.0^{x} \pm 8.62$ & $396.8^{x} \pm 8.36$ \\
\hline \multirow{3}{*}{$\begin{array}{l}\text { Semen } \\
\text { volume } \\
(\mathrm{mL})\end{array}$} & PLW & $232.5^{\mathbf{B}} \pm 7.29$ & $250.9 \pm 7.52$ & $275.9^{\mathrm{A}, \mathrm{X}} \pm 7.54$ & $276.4^{\mathrm{A}, \mathrm{x}} \pm 9.66$ \\
\hline & $\mathrm{PL}$ & $249.7 \pm 6.20$ & $260.3 \pm 5.87$ & $250.8 \pm 6.05$ & $244.9 \pm 5.36$ \\
\hline & $D \times P$ & $247.8 \pm 6.49$ & $248.7 \pm 6.23$ & $243.6^{y} \pm 7.27$ & $240.1^{y} \pm 7.39$ \\
\hline \multirow{3}{*}{$\begin{array}{l}\text { Total number } \\
\text { of sperm } \\
\left(\times 10^{9}\right)\end{array}$} & PLW & $83.5^{Y} \pm 2.19$ & $76.6^{\mathbf{b}, \mathbf{Y}} \pm 1.81$ & $84.9 \pm 1.64$ & $86.6^{a} \pm 2.19$ \\
\hline & $\mathrm{PL}$ & $89.9 \pm 1.80$ & $89.7^{x} \pm 2.03$ & $89.6 \pm 2.02$ & $90.4 \pm 1.92$ \\
\hline & $D \times P$ & $98.2^{\mathrm{A}, \mathrm{X}} \pm 2.15$ & $93.1^{x} \pm 1.92$ & $86.0^{B} \pm 1.91$ & $91.1 \pm 2.25$ \\
\hline \multirow{3}{*}{$\begin{array}{l}\text { Total number } \\
\text { of live sperm } \\
\left(\times 10^{9}\right)\end{array}$} & PLW & $68.7^{\Upsilon} \pm 1.83$ & $63.8^{Y} \pm 1.58$ & $70.7 \pm 1.47$ & $71.7 \pm 1.81$ \\
\hline & $\mathrm{PL}$ & $74.9 \pm 1.56$ & $75.1^{x} \pm 1.81$ & $74.8 \pm 1.83$ & $75.3 \pm 1.62$ \\
\hline & $D \times P$ & $80.9^{\mathrm{A}, \mathrm{X}} \pm 1.76$ & $77.6^{x} \pm 1.70$ & $71.7^{\mathrm{B}} \pm 1.70$ & $76.0 \pm 1.94$ \\
\hline \multirow{3}{*}{$\begin{array}{l}\text { The number of } \\
\text { insemination doses } \\
\text { (n) }\end{array}$} & PLW & $22.6^{\curlyvee} \pm 0.55$ & $21.0^{b, Y} \pm 0.46$ & $22.8 \pm 0.40$ & $23.4^{a} \pm 0.52$ \\
\hline & $\mathrm{PL}$ & $24.3 \pm 0.49$ & $24.2^{\mathrm{x}} \pm 0.44$ & $24.1 \pm 0.48$ & $24.6 \pm 0.46$ \\
\hline & $D \times P$ & $26.0^{\mathrm{A}, \mathrm{X}} \pm 0.51$ & $24.9^{x} \pm 0.46$ & $22.7^{B} \pm 0.49$ & $24.5 \pm 0.53$ \\
\hline
\end{tabular}

Earlier studies have observed an inverse relation between concentration and semen volume (Ciereszko et al., 2000) and this was supported by correlations calculated in our study. The highest sperm concentration was noted in autumn and winter, and the lowest in the higher temperature period of spring and summer, which affected the number of insemination doses. Reduction in concentration and total live sperm in ejaculates is related to the number of insemination doses (Kunavongkrit et al., 2005). Decrease in ambient temperature after summer increases the concentration of sperm in autumn; this is owing to a return to the normal functioning of the testes (Banaszewska et al., 2007). Spring fluctuations in the parameters of ejaculates could be explained by very sudden changes in weather conditions or nutritional deficiencies. However, in wild boars, high correlation coefficients $(r=0.77)$ were observed between concentration and total number of sperm (Kozdrowski \& Dubiel, 2000). A similar trend was noted in own study.

Also, the analysed number of insemination doses received in each season does not allow for an explanation of which time of year can affect the value of this factor, since it depends on the economic efficiency of production. It should be noted that the number of insemination doses is dependent primarily on the concentration and number of live sperm.

The heritability of semen quality is moderate $\left(h^{2} \approx 0.19-0.37\right)$ (See, 2000). Even more so loci may account for the quantity and quality of ejaculates (Lin et al., 2006). Pigs adapt quickly to environmental conditions but these may affect production features including reproduction (Corcuera et al., 2002). Morphological changes in genetics occur with increased frequency, and this happens almost regardless of environmental conditions (Chenoweth, 2005).

Pig production is undertaken in various geographic locations and its intensity is based on polyoestrus and all-year sperm production. It is well known that the conditions under which boars are maintained have a 
significant impact on the quality of their ejaculates (Corcuera et al., 2002). It is believed that during domestication pigs lost their diurnal rhythm of melatonin secretion or it just weakened (Tast et al., 2001). Mediterranean climate research on photoperiod in boars showed no significant differences in semen parameters analysed, although there was a change in concentration and motility (Rivera et al., 2005). Sancho et al. (2004) confirmed that periods with a shorter day length resulted in a sharp decrease in sperm concentration (i.e. $>100 \times 10^{6} / \mathrm{mL}$ ) and total number of sperm (i.e. $\pm 9 \times 10^{9}$ ) in ejaculates.

Photoperiod and temperature influence the action of the testes and epididymis by modulating testosterone production. A clear increase has been observed in its level in spring (Cheon et al., 2002; Park \& $\mathrm{Yi}, 2002)$. Testosterone is necessary to maintain spermatogenesis, particularly through the regulation phase of meiosis. Correct development of spermatocytes can be achieved only by maintaining the appropriate level (Dacheux et al., 2005; Sarlós et al., 2011).

The influence of breed on the semen traits in this study supports the findings of other studies. The highest semen volume with the lowest concentration was noted for the PLW breed, which was also observed in the study by Ciereszko et al. (2000). Higher semen volumes could be explained by the increased secretory activity of the accessory sex glands during summer, related to the photoperiod (Sancho et al., 2006). Park \& Yi (2002) stated that boars from large breeds (e.g. Large White, Yorkshire) have a tendency to produce larger semen volumes, as well as ejaculates with a high number of sperm. It has been proved that testes size is correlated with the ability to produce semen (Umesiobi, 2006). A similar relationship for the PLW breed was shown in our study, although this does not include the total number of sperm in ejaculates.

The breed of boar may exert an influence on some semen parameters during certain seasons (Okere et al., 2005; Banaszewska et al., 2007). The most resistant to environmental factors was PL boars. The PLW and $\mathrm{D} \times \mathrm{P}$ breed demonstrated high variability in relation to outdoor temperature. Kozdrowski \& Dubiel (2004) noted that macroscopic evaluation of wild boar and boar semen demonstrated no differences, and only slight seasonal changes were shown. In their research for the analysed boar semen, an inverse relation was observed in the semen volume compared with wild boars. Lower results were obtained by Sancho et al. (2004) for Landrace boars in autumn, compared with our own results. Nearly $50 \%$ lower sperm concentrations, total numbers of sperm in ejaculates and the number of insemination doses were shown for Landrace boars.

The relationship between the various parameters is variable by breed and individual. A positive correlation was demonstrated among sperm concentration and testes activity (Ciereszko et al., 2000). On the other hand, crossbreed boars produced more sperm in ejaculates (Smital et al., 2004), as is confirmed in our research. Crossbreed boars play a major role in cross-breeding programmes to improve production and reproductive efficiency (Knecht et al., 2004). The breed of boar also had a significant effect on the semen parameters in terms of compared seasons.

\section{Conclusions}

Our findings supported other studies in that the season of semen collection and breed of boar influence the quantity and quality of selected parameters of ejaculates. This translated into the most important factor for Al centres, the number of insemination doses. In summer in particular, a suitable number of donor boars (specific breeds) should be maintained in order to guarantee the appropriate number of insemination doses and for better organization of insemination stations. It is recommended that new boars should be introduced in the late winter, and the old boars of the herd should be culled in the autumn. This will help maintain continuity of production.

\section{Acknowledgements}

The authors would like to thank English native speaker K. Bernhardt for revising and editing the language of the manuscript.

\section{References}

Banaszewska, D., Kondracki, S. \& Wysokińska, A., 2007. The influence of the season on the sperm morphology young boars used for insemination. Acta Sci. Pol. Zootechnica 6, 3-14. (in Polish, English abstract).

Basset, J.M., Bray, C.J. \& Sharpe, C.E., 2001. Reproductive seasonality in domestic sows kept outdoors without boars. Reproduction 121, 613-629.

Bennett, G.H. \& O'Hagan, C., 1964. Factors influencing the success of artificial insemination in pigs. Proc. Vth Int. Congr. Anim. Reprod. 4, 481.

Blomberg, J.M., Bjerrum, P.J., Nielsen, J.E., Joensen, U.N., Olesen, I.A., Petersen, J.H., Juul, A., Dissing, S. \& Jorgensen, N., 2011. Vitamin D is positively associated with sperm motility and increases intracellular calcium in human spermatozoa. Hum. Reprod. 26, 1307-1317. 
Bouillon, R., Carmeliet, G., Verlinden, L., Van Etten, E.E., Verstuyf, A., Luderer, H.F., Lieben, L., Mathieu, C. \& Demay, M., 2008. Vitamin D and human health: lessons from vitamin D receptor null mice. Endocr. Rev. 29, 726-776.

Chenoweth, P.J., 2005. Genetic sperm defects. Theriogenology 64, 457-468.

Cheon, Y.M., Kim, H.K., Yang, C.B., Yi, Y.J. \& Park, S.C., 2002. Effect of season influencing semen characteristics, frozen-thawed sperm viability and testosterone concentration in Duroc boars, AsianAust. J. Anim. Sci. 1, 500-503.

Chokoe, T.C. \& Siebrits, F.K., 2009. Effects of season and regulated photoperiod on the reproductive performance of sows. S. Afr. J. Anim. Sci. 39, 45-54.

Ciereszko, A., Ottobre, J.S. \& Glogowski, J., 2000. Effects of season and breed on sperm acrosin activity and semen quality of boars. Anim. Reprod. Sci. 64, 89-96.

Claus, R. \& Weiler, U., 1985. Influence of light and photoperiodicity on pig prolificacy. J. Reprod. Fertil. Suppl. 33, 185-197.

Colenbrander, B. \& Kemp, B., 1990. Factors influencing semen quality pigs. J. Reprod. Fertil. Suppl. 40, 105-115.

Colenbrander, B., Feitsma, H. \& Grooten, H.J., 1993. Optimizing semen production for artificial insemination in swine. J. Reprod. Fertil. Suppl. 48, 207-215.

Corcuera, B.D., Hernandez-Gil, R., De Alba Romero, C. \& Martin Rillo, S., 2002. Relationship of environment temperature and boar facilities with seminal quality. Livest. Prod. Sci. 74, 55-62.

Dacheux, J.L., Castella, S., Gatti, J.L. \& Dacheux, F., 2005. Epididymal cell secretory activities and the role of proteins in boar sperm maturation. Theriogenology 63, 319-341.

Flowers, W.L., 2008. Genetic and phenotypic variation in reproductive traits of Al boars. Theriogenology 70 , 1297-1303.

Ford, J.J., McCoard, S.A., Wise, T.H., Lunstra, D.D. \& Rohrer, G.A., 2006. Genetic variation in sperm production. Soc. Reprod. Fertil. Suppl. 62, 99-112.

Gerrits, R.J., Lunney, J.K., Johnson, L.A., Pursel, V.G., Kraeling, R.R., Rohrer, G.A. \& Dobrinsky, J.R., 2005. Perspectives for artificial insemination and genomics to improve global swine populations. Theriogenology 63, 283-299.

King, G.J. \& Macpherson, J.W., 1973. A comparison of two methods for boar semen collection. J. Anim. Sci. 36, 563-565.

Kinuta, K., Tanaka, H., Moriwake, T., Aya, K., Kato, S. \& Seino, Y., 2000. Vitamin D is an important factor in estrogen biosynthesis of both female and male gonads. Endocrinology 141, 1317-1324.

Knecht, D., Jasek, S., Procak, A. \& Krzyżewski, P., 2004. Efficiency of inseminating sows with pure breed and crossbreed boars. Med. Weter. 60, 1208-1211. (in Polish, English abstract).

Kozdrowski, R. \& Dubiel, A., 2004. The effect of season on the properties of wild boar (Sus scrofa L.) semen. Anim. Reprod. Sci. 80, 281-289.

Kunavongkrit, A., Suriyasomboon, A., Lundeheim, N., Heard, T.W. \& Einarsson, S., 2005. Management and sperm production of boars under differing environmental conditions. Theriogenology 63, 657-667.

Lin, C.L., Ponsuksili, S., Tholen, E., Jennen, D.G.J., Schellander, K. \& Wimmers, K., 2006. Candidate gene markers for sperm quality and fertility of boar. Anim. Reprod. Sci. 92, 349-363.

Okere, C., Joseph, H. \& Ezekwe, M., 2005. Seasonal and genotype variations in libido, semen production and quality in artificial insemination boars. J. Anim. Vet. Adv. 4, 885-888.

Okwun, O.E., Igboeli, G., Ford, J.J., Lunstra, D.D. \& Johnson, L., 1996. Number and function of Sertoli cells, number and yield of spermatogonia, and daily sperm production in three breeds of boar. J. Reprod. Fertil. 107, 137-149.

Ordinance of the Minister of Agriculture and Rural Development, 15 February 2010.

Park, C.S. \& Yi, Y.J., 2002. Comparison of semen characteristics, sperm freezability and testosterone concentration between Duroc and Yorkshire boars during season. Anim. Reprod. Sci. 73, 53-61.

Peltoniemi, O.A.T., Tast, A. \& Love, R.J., 2000. Factors effecting reproduction in the pig: seasonal effects and restricted feeding of the pregnant gilt and sow. Anim. Reprod. Sci. 60-61, 173-184.

Polish Swine Nutrition Requirements, 1993. The Kielanowski Institute Animal Physiology and Nutrition, Polish Academy of Sciences. Omnitech-Press, Warsaw, Poland. (in Polish).

Popiołek, M., Knecht, D., Szczęsna-Staśkiewicz, J. \& Czerwińska-Rozałow, A., 2010. Helminths of the wild boar (sus scrofa L.) in natural and breeding conditions. Bull. Vet. Inst. Pulawy 54, 161-166.

Ren, D., Xing, Y., Lin, M., Wu, Y., Li, K., Li, W., Yang, S., Guo, T., Ren, J., Ma, J., Lan, L. \& Huang, L., 2009. Evaluations of boar gonad development: Spermatogenesis with regard to semen characteristics, libido and serum testosterone levels based on large White Duroc $\times$ Chinese Erhualian crossbred boars. Reprod. Domest. Anim. 44, 913-919. 
Rivera, M.M., Quintero-Moreno, A., Barrera, X., Palomo, M.J., Rigau, T. \& Rodriguez-Gil, J.E., 2005. Natural Mediterranean photoperiod does not affect the main parameters of boar-semen quality analysis. Theriogenology 64, 934-946.

Robinson, J.A.B. \& Buhr, M.M., 2005. Impact of genetic selection on management of boar replacement. Theriogenology 63, 668-678.

Safranski, T.J., 2008. Genetic selection of boars. Theriogenology 70, 1310-1316.

Sancho, S., Pinart, E., Briz, M., Garcia-Gil, N., Badia, E., Bassols, J., Kadar, E., Pruneda, A., Bussalleu, E., Yeste, M., Coll, M.G. \& Bonet, S., 2004. Semen quality of postpubertal boars during increasing and decreasing natural photoperiods. Theriogenology 62, 1271-1282.

Sancho, S., Rodriguez-Gil, J.E., Pinart, E., Briz, M., Garcia-Gil, N., Badia, E., Bassols, J., Pruneda, A., Bussalleu, E., Yeste, M., Casas, I., Palomo, M.J., Ramio, L. \& Bonet, S., 2006. Effects of exposing boars to different artificial light regimens on semen plasma markers and "in vivo" fertilizing capacity. Theriogenology 65, 317-331.

Sarlós, P., Egerszegi, I., Nagy, Sz., Fébel, H. \& Rátky, J., 2011. Reproductive function of Hungarian Mangalica boars: Effect of seasons. Acta Vet. Hung. 59, 257-267.

See, M.T., 2000. Selection for Al stud traits. In: Record of Proceedings National Swine Improvement Federation Conference and Annual Meeting, Nashville, Tennessee, USA, 7-8 December (NSIF 25).

Smital, J., De Sousa, L.L. \& Mohsen, A., 2004. Differences among breeds and manifestation of heterosis in Al boar sperm output. Anim. Reprod. Sci. 80, 121-130.

Sonderman, J.P. \& Luebbe, J.J., 2008. Semen production and fertility issues related to differences in genetic lines of boars. Theriogenology 70, 1380-1383.

STATISTICA, 2012. Data Analysis, Software System. Version 10 StatSoft Inc.

Strzeżek, J., Fraser, L., Demianowicz, W., Kordan, W., Wysocki, P. \& Hołody, D., 2000. Effect of depletion tests (DP) on the composition of boar semen. Theriogenology 54, 949-963.

Tast, A., Halli, O., Ahlstrom, S., Andersson, H., Love, R.J. \& Peltoniemi, O.A.T., 2001. Seasonal alterations in circadian melatonin rhythms of the European wild boar and domestic gilt. J. Pineal. Res. 30, 43-49.

Umesiobi, D.O., 2006. The effect of hemi-orchidectomy on reproductive traits of boars. S. Afr. J. Anim. Sci. 36, 181-188.

Wetteman, R.P. \& Bazer, F.W., 1985. Influence of environmental temperature on prolificacy of pigs. J. Reprod. Fertil. Suppl. 33, 199-208.

Wolf, J. \& Smital, J., 2009. Quantification of factors affecting semen traits in Al boars from animal model analyses. J. Anim. Sci. 87, 1620-1627. 